\title{
SYMBOLIC INTERPRETATIONS IN MEDYA HUS'S POEMS IN ACEHNESE
}

\author{
Nazira Putri \\ I Wayan Dirgeyasa \\ Lidiman Sahat Martua Sinaga \\ Universitas Negeri Medan
}

\begin{abstract}
Principally this research attempts to find out the symbols and reasons displayed in Medya Hus's Poems in Acehnese. This study was conducted by using descriptive qualitative method. The sources of the data were the poems in 'Jameun Internet' book by Medya Hus in Acehnese. The instrument for collecting data are documentary sheet. The data were analyzed by using Pierce's theory of semiotic. The writer found 22 meanings were displayed in the Medya Hus's poems. They were Aki wèt-wèt (3,33\%), Budôk (3,33), Engkôut (3,33\%), Ujeuen (3,33), Zakéut (3,33\%), Teukabo (3,33\%), Kayèe Syuruga (3,33\%), Syuruga Lapan (3,33\%), 'Arasy (3,33\%), Rabôn $(3,33 \%)$, Qur'an ngon Hadis (3,33\%), Nuraka (3,33\%), Agama (20\%), Lampu $(3,33)$, Bohaté $(3,33 \%)$, Mata Beungah (3,33\%), Kapai (3,33\%), Syèthan (3,33\%), Ratéb (6,7\%), Syuruga (10\%), Tasbèh (3,33\%), Taqwa (3,33\%). In the poems contain of different symbols and meaning. Medya Hus almost used the symbols that related to Islamic concept to show the roles of Islam in Aceh and explained the Acehnese culture and society, and nature.
\end{abstract}

Keywords: Acehnese Poems, Medya Hus's Poems, Pierce's Theory, Symbolic, Semiotic,

\section{INTRODUCTION}

Semiotics is the study of signs and symbols and their use of interpretation. Usually, semiotic analysis studies the roles of signs and the part they play on a social and cultural scale. Semiotics is used to inform the reader of what interpretation he/she should make in regards to the sign. It includes the study of how meaning is constructed and understood.

Taufiqqurohman (2016) stated in his journal, Semiotics as the knowledge on sign, has two principles, namely signifier and signified. According to Pierce as has been quoted by Pradopo (1995:121), based on the relation between the signifier and the signified, there are three kinds of basic sign, they are icon, index and symbol. Icon has a similar relationship between the signifier and the signified such as photograph with the man photographed. Index is the relation shows cause and effect like smoke beckons fire. Meanwhile, symbol shows arbitrary relations based on the convention of people generally. It is like language.

In literature side, there are many sign can be found, such in song and poem. Songs and poems have special characteristic in their lyric and verse. Song and poem generally conveys message and meanings. Poetry as a kind of literary work is a reflection of poet's thought and feelings. Poems are like the fingerprints of the poet. They tell you what the poet was thinking, what frame of mind he or she was in. Poets are love with words. The gift of language makes of human, and poets make the fullest of it.

As a unique media of communication, poem is created in a brief and concentrated form of language. Each poem contains different symbols with different meaning and function. All of these differences had given different ideas. 
Poem does this through an intricate pattern of words, and it offers language as highly organized as language as can be. No word is idle or accidental, each word has a specific place within an overaching pattern. Together they create meaningful and beautiful words.

We can find out what the poem tells about from the symbol. Some poets who used symbols in their literary works are Moehammadyah Husen or also known as Medya Hus is the one of famous poets in Aceh. He writes the poems since 1983, his works are often strange and highly imaginative. He writes the poems contain of symbols. He very interested in symbols, many of her poems show symbols that very meaningful in expressing her idea. Symbols for her are very important part to manipulate and create the special characteristic of her poems. However, he doesn't write poem about love, he prefers to writes about aceh's culture and religion as Dakwah.

Acehnese displays exceptionally rich and distinguished poetic traditions. The various kinds and uses of poem are described in some detail. This is significant since virtually all achenese written texts, which serves a wide range of functions in the life of Acehnese people, are in verse. Mostly the acehnese poems is not about love, however the poets prefer to write about the Aceh's culture and religion, because Islam is the dominant religion in Aceh.

The object of the study was a book from Medya Hus's book entitle 'Jameun Internet', this book that contain of 18 poems. The scope of the study deals with the subject matter of Medya Hus's poems in Acehnese. This research conducts to describe the meaning of each symbols in 'Jameun Internet' book by Medya Hus's poem in Acehnese, entitled: Jameun Internet, Rahmat Allah, Kayèe Syuruga, Meurunoe, Beudoh, Bèk Beu O, Akhlaq Mulia, Haba, and Duek. And elaborate the reasons of symbol used in the poems, based on Charles Sanders Peirce's semiotic theory.

By doing this research, there are some theories that needed to give some explainations of proof, to give some clearer concepts which are applied in this study, in order to prevent misunderstanding among the writer, and also to avoid the misinterpretation of the term used. It is dealing with semiotics. The concept will lead to be better analysis of the variables chosen because it helped the researcher to limit the scope of the problem. Theories also formulated to explain, predict, and understand phenomenon and in many cases, to challenge and extend existing knowledge within the limits of critical bounding assumptions. A theoritical framework consists of concepts and together with their definitions and reference to relevance scholarly literature, existing theory that is used for particular study.

\section{Symbols}

According to Nims and Mason (1998:93), Symbolic poems are not less satisfactory when we cannot provide the symbols with and exact meaning. In fact, it often seems the most compelling symbols direct us to an area of speculation rather than to any single reality.

A symbol is an object or event that suggest more than itself. It is one of the most common and most powerful devices available to the poet, for it allows him to convey economically and simply a wide range of meanings (Abcarian and Klotz, 1980). Poets such as William Blake and W.B Yeats often use symbols 
when they believe in or seek a transcendental (religious or spiritual) reality. For example, a rose, can present of love or beauty.

\section{Semiotic}

Semiotic involves the study not only of what we refer to as 'signs' in everyday speech, but anything which 'stands for' something else. In a semiotic sense, signs take the form of words, images, sounds, gestures and objects. Contemporary semioticians study signs not in isolation but as part of semiotic 'sign-systems' (such as a medium or genre). They study how meanings are made and how reality is represented (Chandler, 2007:2).

Perhaps unsurprisingly, given its centrality in culture, the scrutiny of the nature of signs has commonly been conducted through a distorting human lens. In these instances, signs have usually been considered to be connected to the human capacity for language and ensuing cultural products, with a bias towards the verbal. Thus, it is easy to imagine that the study of signs, semiotics, in spite of a long lineage which will become apparent throughout this volume, is somehow a matter of analysing language and discovering how various artefacts and processes of human culture are analogous to it (Paul Cobley, 2005:3).

The definition of some experts, semiotics is a general study about the signs as an essential part of culture life and communication. According to the explaination of Daniel Chandler, the interpretation of semiotics not only about the everyday speech, but the form of sounds, images, gestures, and objects. In language, there are some codes in vocabulary of the sentence for building more elaborates meanings, and how the reality is presented. Shortly, sign is connected to the human life. For instance, the sign in the different colours of a traffic light, without even thinking about it, everybody automatically knows how to react to them. But this is a sign which has been established by cultural convention over a long period of time and requires a deal of unconscious cultural knowledge to understand its meaning.

As the theory of interpretation in the culture life, semiotic has two fundemental founders, between Ferdinand de Saussure and Charles Sander Pierce. These two founders put the fundemental aspect in semiotic through ontological and epistemological.

Between these two experts of Semiotics, each of them develops the different type and characteristic of semiotic. Saussure as the founder of the modern linguists build the semiotic based on the language as the system of the sign. And Pierce build the theory of semiotic based on the pragmatic and logic philosophy. Generally, most of the expert of the semiotic differs between the semiotics of significantion based on the Saussure, and semiotics of communication which based on Pierce logical and pragmatic philosophy. Actually in these two differences has a same interaction each other, even in the system of the language sign and in the communication as the language context.

\section{Semiotics Theories}

\section{a) Ferdinand de Saussure}

In Saussure's theory, there are three element distinctions according to his Course in General Linguistic book as the fundemental element of the structural semiotic approach, semiotics is divided into two parts, between (1) Dichotomy; a 
marker (signifier) and the sign (signified), (2) language, parole, and langue, (3) synchronic and diachronic. Markers seen as a form/physical form, can be known through the work of architectural form, is being seen as a sign of meaning is revealed through the concept, function and/or values contained works of architecture. Saussure defined the linguistic sign as being made up of the matched pair of signifier and signified. A signifier is the thoroughly material aspect of a sign. If one feels ones vocal when speaking, it is clear that are made from vibrations (which are undoubtedly material in nature) then Saussure describes the verbal signifier as a sound image (Cobley and Jansz, 1997:10). In communicating, someone using signs to send the meaning of objects and other people will interpret these using signs. For instance, when someone say the word "run" (signifier) with swearing tone then it is a sign of bad situation in the place (signified).

\section{b) Charles Sanders Peirce}

In this term, Pierce determines the subject of the sign as the part that unseparated from the process of the signification. In his defination, Pierce says that there are three sides of sign: sign/representamen, object, and interpretant, show the important role of the subject in the language transformation.

The interaction between the representamen, the object and the interpretant is called as semeiosis (Chandler, 2007: 30). Each sign must have these three components, they are:

\section{1) Representamen}

What usually goes for a sign everyday talk, Pierce called a representamen. Chandler (2007:258) states that the representamen is one of the three elements of Pierce's model of the sign and it refers to the form which the sign takes.

He did so in order to differ the representamen from the order two sign components that as we shall note, can become signs in their own right. The representamen is something that enters into related with its object, the second component of the sign. It is some phenomenon that an individual can see, hear, sense, or imagine.

\section{2) Object}

The second component is object. Peirce defines object is something beyond the sign to which it refers (a referent). The object in semiotics can never be identical to the 'real object', since according to Pierce's our knowledge is never absolute. Our knowledge can be no more than an approximation to the 'real' world exactly as it is, or better, is becoming. So that, in a manner of putting it, 'the semiotically real object' we smell, taste, touch, hear, and see is never identical to the 'really real object'. We simply can not know the world just as it is becoming: our minds are too limited and it is so substle and complex. Consequently, since this 'real object' cannot be completely known once and for all, it can never be more than 'semiotically real' for its interpreters.

Refer to the theory of Pierce, based on its object, the next three types of signs are taken from Peirce 's classification of signs as, Icons, indexes, and symbols.

a) Icon

An icon is a sign that is made to resemble, simulate, or reproduce its referent in some way. Photographs may be iconic signs because they can be seen to reproduce their referents in a visual way. 
b) Index

An index is a sign that refers to something or someone in terms of its existence or location in time or space, or in relation to something or someone else. An index is a sign which indicates the existence of a natural affinity between sign and signified that is causal or causal relationship, or signs which direct reference to reality. The most obvious example is the smoke as a sign of fire.

c) Symbol

A symbol is a sign that stands for its referent in an arbitrary, conventional way. Words in general are symbolic signs. But any signifier - object, sound, figure, etc. -can be symbolic.

\section{3) Interpretant}

Interpretant or the usage of sign is a concept of thinking from the people who use a sign and give it a special meaning or meaning that people have in their minds about an object which is referred by the sign. The most important thing is in the process of semiotic is how the meaning occurs from a sign when the sign is used by the people to communicate.

These are best known as trichotomy of Pierce's theory. The trichotomy can be visualized in this triangle:

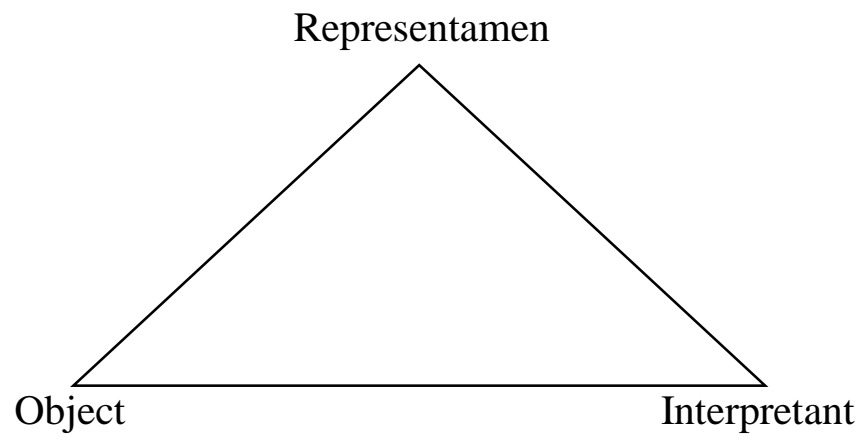

Figure 2.1 The Process of Linguistic Sign

The interaction between the reprentamen, the object and the Interpretant is referred to by Pierce as 'semiosis' theory.

Symbols are divisible by three trichotomies. First, according as the symbol in itself is a mere quality, is an actual existent, is a general law. Secondly, according as the relation of the symbol to its object consists in the symbol's having some character in itself, or in some existential to that object, or in its relation to an interpretant. Thirdly, according as its interpretant represents it as a symbol of possibility or as a symbol of fact or a symbol of reason.

\section{Interpretation}

Ham (1992) quoted that interpretation is "an educational activity which aim; to reveal meanings; and relationship through the use of original objects, by first hand's experience, and by illustrative media, rather than simply to communicate factual information." It means that interpretation is an approach to communicate which stresses the transfer of ideas relationship rather than isolated facts and fugures. Although interpreters use factual information to illustrate points and clarify meanings, it is the points and meanings that he or she is trying to communicate, not the facts. 
The interpretation makes links between tangibles, intangibles and universal concepts. The power of the resources we interpret comes from their capacity to reveal meanings, the intangible qualities of the place or events, those things that move our soul (Beck and Cable, 1998). The charge of the interpreter then is to help making the connection between the tangible and intangible meanings of the resource in the hearts and minds of the audiences. An entire group on intangible can be labeled "universal concepts" like beauty, freedom, community and courage because almost everyone can relate to them, but not in the same way. It is a creative act to reveal deeper meanings from tangible objects and to relate those meanings to universal concepts. Each interpreter will interpret differently, just as each person will respond differently to the interpretation.

\section{Semiotic Interpretation}

A sign is not only something which stands for something else; it is also something that can and must be interpreted. The criterion of interpretability allows us to start from a given sign to cover, step by step, the whole universe of semiosis (Eco, 1986:46).

Symbol is not an expression of everyday language. A word such as sign occurs in many ready-made syntagms, and when one is unable to give a univocal definition of the isolated term, one is still able to give a certain in terpretation of these syntagms. It is, on the contrary, the pseudo everyday language of the press or of literary criticism that says that certain merchandises are the symbol of the productivity of a given country, that Marilyn Monroe was a sex symbol, that the terrorists attempted to assassinate the American ambassador in Rome for symbolic reasons, that a certain word, description, or episode has to be read symbolically. A common speaker would have some difficulty in explaining the 'right' sense of these and of other similar expressions (Eco, 1986:132).

\section{Acehnese Poem}

Poems or in Acehnese language is also known as caé, is one of the divisions of the literary variety of Aceh. Acehnese people uses caé to express their intentions to their opponents, because the Acehnese people have their own talents in poems. According to Harun (2012:6) stated that, "For Acehnese people, the term caé is often used for the purpose of rhymes or other types of rhythmic language, especially if it is spoken verbally". Based on that theory, the poem or caé in the everyday life of the Acehnese people is also used in rhyming even in various other rhythmic languages, especially if delevered verbally. So for Acehnese people, caé opens themself to be used in various types of rhythmic language.

\section{Culture}

Culture is the form of traditional behavior that is built by the members of society to show their identity or characteristic, includes belief, knowledge, law, morals, etc. Culture has been formed by the way in which people think and do things. All the achievements of human beings as members of social group called culture. In general meaning, culture is the result of what people have done in the past time which the value of the action is expensive and important until now. Culture is the expression of nature in modes living and thinking. 
There are so many culture in the world. Each country has a different culture. Each people in one place or group of people also has a different culture in their life. It means that, every people submit their own culture. Culture as a characteristics of a particular group of people is defined by everything from language, religion, cuisine, social habits, music and arts.

\section{a) Indonesian Culture}

Indonesia is a country that has very rich culture. Each island consists of several provinces that have different culture. Each tribe has its own language, costums house, dance, folk songs, traditional clothes, traditional ceremonies, traditional food, etc. In Indonesia, there are many different cultures, this makes Indonesia become a complex country and therefore this fascinating country. As noted below, there are some culture in Indonesia, such as Bataknese, Malaynese, Javanese, Acehnese, etc. However in this research, the writer only focus in Acehnese culture.

\section{b) Acehnese Culture}

Aceh is one of some province in Indonesia, which is located at the Northern end of Sumatera. Its full name of aceh is Naggroe Aceh Darussalam, the capital and largest city is Banda Aceh. It has a population around of 4,2 million, its major towns includes; Banda Aceh, Lhokseumawe, Meulaboh, Sigli, and Calang. The island of Sabang (an hour's ferry ride from Banda Aceh), considered a diver's and snorkeler's paradise, belongs to the province. There are three major ethnic groups in Aceh; Acehnese, Gayo and Alas.

Aceh is a multicultural province within a multicultural state. Aceh has a rich culture traditional that is covered in its language, food, art, dance and costums. However, Aceh has a lot of potential cultures which are basically colored by Islamic religion, because the dominant religion of Aceh is Islam (moslem).

To support this research, there are some relevant studies to this research that have been made by other researchers. These relevant studies also will be used as references and guidance to help the researcher have a deep understanding about signs, so that the author can coduct her own study in a good way.

The first previous study is conducted by Hermawan (2010), in his research paper there are three kind of Kim Oddonizio's poems constructed by the symbol as one kind of intrinsic element of poetry. The researcher found 3 symbols in Varieties' poem, the appearances of symbol are represented by the words Varieties, Ax, and Darkest hour. In First poem for You's poem, the appearances of symbol are represented by the words Lightening, Water, Serpent, and pictures. And in What Do Women Want's poem, the researcher found the appearances of symbol are represented by the words Dress, Sleeveless, Backless, and Grament. The use of symbol in What Do Women Want is describes as the power of her sexuality, freedom and equality. Kim Oddonizio almost uses the symbol of nature and also the symbol of society and silent thing in her these poems. For doing this research, the researcher utilized triadic-theory of semiotic process which are proposed by Charles Sanders Pierce to know the meaning of each symbol, they are, representament, interpretant and object.

The second research related to this study was conducted by Setiawan (2014), in her research focuses to analysis the meaning of symbols in Robert 
Frost's poems, the writer analyzed three poems by Robert Frost, and the writer used theory of Charles Sanders Pierce semiotics theory. This research found that symbol can be seen in the poem, in the poem 'the road not taken' the writer found that this poem describes a person has two choices in life. In the second poem 'Fire and Ice', the poem implies the symbols that represent way of life in which the life has spirit or fire to struggle. And the last poem ' Stopping by Woods on a Snowy Evening' implies symbols that represent what kinds of spirits we struggle.

The third research related to this study was conducted by Singh (2011), in this research, the writer analyzed the symbol used in T.S Eliot's poetry with special reference to "The Waste Land". After she analyzed the poem, she concluded that Eliot has used a lot of symbols are at once centered round the basic theme of the poem i.e. birth-death-rebirth. Most of the symbols used in the poem are drawn from ancient myths and religions from the European literary tradition and some from the Bible. The symbol are used not express personal sensations, rather they are used to depict a complex abd decadent civilization with all soul killing monotony and meaningless routine. And Eliot has used symbols not as an ornament but employed them as the only mean available for communication for certain levels of experience which are not available to us though direct perception. From the few studies that analyze about the analysis of semiotic in poems, there are some similarities and differences between this research and the previous studies. The similarities of previous studies and this study is anlyze about symbols in poem, and focus of how the poet convey the ideas of the poems. But different is in the object of the research. However the uniqueness of this research than the previous studies is this research analyze the poems that uses the local language and the poems mostly contains the story of culture and religion.

\section{RESEARCH METHODOLOGY}

This research is qualitative method which to find out and describes the symbols on Medya Hus's Poems in Acehnese and then those symbols were interpreted by Charles Sanders Pierce. Qualitative research is concerned with the qualitative phenomenon, such as a phenomena relating to or involving quality or kind.

The data took from a book by Medya Hus' book entitle "Jameun Internet". The title "Jameun Internet" used Aceh language, in english translated "The Era of Internet", this book contains 18 poems by Medya Hus, but the writer only analyzed 9 poems that contains the symbols, because this 9 poems qualified to identify the symbols based on the theory of this research and it offers us high points of emotion, reflection, thought, and feeling. Robert and Jacobs (2001:1) state that literature is a form of writing that tells a story with dramatic situations and emotional expression.

This book were written in Aceh language and was created in 2009 to 2012. The data of this study is in form of words, phrases, clauses or sentences found in the book.

To do this research, the data were collected by using documentary technique. The Instrument is a tool for collecting data and it plays a very significant roles that greatly determines the results of the study. The documentary sheets of the study is a Book. A book entitle "Jameun Internet" by Medya Hus. 
In analyzing the data, descriptive qualitative analysis technique was used by the following steps: 1) Identify the symbol based on Peirce's theory in each poems in "Jameun Internet" book by Medya Hus, entitled: Jameun Internet, Rahmat Allah, Kayèe Syuruga, Meurunoe, Beudoh, Bèk Beu O, Akhlaq Mulia, $H a b a$, and Duek; 2) Reduction occurs continually throughout the analysis. This also needs note taking to reduce the source data which is not related with the study; 3 ) Analyze the meaning and reason of the symbols used in each poems in "Jameun Internet" book by Medya Hus, entitled: Jameun Internet, Rahmat Allah Kayèe Syuruga, Meurunoe, Beudoh, Bèk Beu O, Akhlaq Mulia, Haba, and Duek; 4) Drawing Conclusion, conclusing the results of the data based on the research problems of this study. After all data have been identified, the conclusion will be drawn into answer of the research problems.

\section{RESEARCH FINDINGS AND DISCUSSION}

Table 1. Symbols used in poems in 'Jameun Internet' book by Medya Hus in Acehnese

\begin{tabular}{|l|l|l|l|}
\hline No. & Symbol & Frequency & Percentage \\
\hline 1. & Aki wèt-wèt & 1 & 3,33 \\
\hline 2. & Budôk & 1 & 3,33 \\
\hline 3. & Engkôut & 1 & 3,33 \\
\hline 4. & Ujeuen & 1 & 3,33 \\
\hline 5. & Zakéut & 1 & 3,33 \\
\hline 6. & Teukabo & 1 & 3,33 \\
\hline 7. & Kayèe Syuruga & 1 & 3,33 \\
\hline 8. & Syuruga Lapan & 1 & 3,33 \\
\hline 9. & 'Arasy & 1 & 3,33 \\
\hline 10. & Rabôn & 1 & 3,33 \\
\hline 11. & Qur'an ngon Hadis & 1 & 3,33 \\
\hline 12. & Nuraka & 1 & 3,33 \\
\hline 13. & Agama & 6 & 20 \\
\hline 14. & Lampu & 1 & 3,33 \\
\hline 15. & Bohaté & 1 & 3,33 \\
\hline 16. & Mata Beungah & 1 & 3,33 \\
\hline 17. & Kapai & 1 & 3,33 \\
\hline 18. & Syèthan & 1 & 3,33 \\
\hline 19. & Ratéb & 2 & 6,7 \\
\hline 20. & Syuruga & 3 & 10 \\
\hline 21. & Tasbèh & 1 & 3,33 \\
\hline 22. & Taqwa & 1 & 3,33 \\
\hline & Total & $\mathbf{3 0}$ & $\mathbf{1 0 0}$ \\
\hline & & & \\
\hline
\end{tabular}

Based on the Table 4.1, there were only 30 symbols used in 9 poems in 'Jameun Internet' book by Medya Hus in Acehnese, entitled: Jameun Internet, Rahmat Allah, Kayèe Syuruga, Meurunoe, Beudoh, Bèk Beu O, Akhlaq Mulia, Haba, and Duek. It was 22 symbols were found in Medya Hus's poems in 'Jameun Internet' book in Acehnese, entitled: Jameun Internet, Kayèe Syuruga, Meurunoe, Beudoh, Bèk Beu O, Akhlaq Mulia, Haba, Duek, and Rahmat Allah.

Medya Hus mostly used the Islamic terms as the symbols to express what he wants to convey in his poems, because almost of Medya Hus's poems related to Islamic concept. And he also used the things and sensory organ as the symbol. 
And the reasons of using the symbols in Medya Hus's poems, because Medya Hus wants to show the Acehnese culture and their atittude in society, especially about the roles of religion in Aceh. And also to describe about the nature in Aceh.

\section{DISCUSSION}

Related to the previous studies, the finding of this study was supported by Hermawan (2010), he analyzed three poems by Kim Addonizio, they are Varieties, First Poem for You, and What do Women Want. The poems constructed by the symbol as one kind of intrinsic element of poetry. To do this research, he used the triadic-theory of semiotic process which are proposed by Charles Sanders Peirce. Finally, he found that Kim Addonizio almost uses the symbol of nature, the symbol of society and also the symbol of silent thing in her three poems.

Setiawan (2014), he analyzed three poems by Robert Frost, entitled The Road not Taken, Fire and Ice, and Stopping by Woods on a Snowy Evening in her research found the symbols that indicate same meaning or some themes that is a way of life that must be passed, and among the symbols there is an increase or a relationship in the three poems. The writer used the triadic-theory of semiotic process which are proposed by Charles Sanders Pierce to know the meaning of each symbols.

Singh (2011), this research analyzed the symbol used in T.S Eliot's poetry with special reference to "The Waste Land". After she analyzed the poem, she concluded that most of the symbols used in the poem are drawn from ancient myths and religions from the European literary tradition and some from the Bible. And the poet has used symbols not as an ornament but employed them as the only mean available for communication for certain levels of experience which are not available to us though direct perception.

In this research, the writer focused to analyze 9 poems in 'Jameun Internet' book by Medya Hus in Acehnese, and using the triadic-theory of semiotic process that proposed by Charles Sanders Pierce (1991). To do this research, first the writer deals with the meaning of each line from the poems to find out the symbols. Second, the analysis deals with theory of Charles Sanders Peirce that symbol can be understood by the process of semiosis. The following description of the process of semiosis are Perception "represent" (R) are seen by humans (this is called the "sign"), referral "represent" on the object $(\mathrm{O})$ which is a concept known by user sign. And Interpretation of the meaning interpreting (I) by the user sign after "represent" associated with the object.

In this research, most of the symbols used in the poems by Medya Hus are the symbols of religion, such as Ratèb, Zakeut, Taqwa, Tasbeh, Qur'an ngon Hadis, etc. The religion symbols also found in the research of Singh (2011), most of the symbols used in the poem are drawn from ancient myths and religions from the European literary tradition and some from Bible. But in Medya Hus's poems, the religion symbols aren't from Bible, but all the symbols refers to the Islamic concept, which means from the Al-Qur'an as the holy book of Islam.

The next symbols found in Medya Hus's poems are the symbol of nature, such as Engkeuet and Rain, and silent things to illustrate the goodness of God as the creaturer, such as 'Arasy, Syuruga Lapan, etc. And all of these symbols are to express his thankful to God. In Hermawan (2015) research, he also found that 
Kim Addonzio almost uses the symbol of nature and also the symbol of society and silent thing in her three poems, but in her research explained that Kim Addonzio used these symbols to express the ideas about sadness, love, sexuality, freedom and equal right.

Medya Hus also used the symbol to convey his ideas about the spiritual nature or behavior of Aceh people, such as Aki wèt-wè, bohatè and Mata beungah. He used the part of body as the symbols to convey his meaning about the sad perspective of Acehnese people in his poems. And used the sensory organ, bohatè, as the symbol in his poem to show his affection to the readers.

The last symbols used in Medya Hus poems is the symbol to explain about life, especially about how should Aceh people behave in society, the meaning of these symbols also contain about his advices to the readers and has deep meaning, such as Kapai, Lampu and Rabôn.

\section{CONCLUSION AND SUGGESTION}

\section{Conclusion}

From the analysis, the symbols in 'Jameun Internet' book by Medya Hus in Acehnese, entitled: Jameun Internet, Kayèe Syuruga, Meurunoe, Beudoh, Bèk Beu O, Akhlaq Mulia, Haba, Duek, and Rahmat Allah had founded. The data which consist of words, phrases, and sentences found in 9 poems by Medya Hus in Acehnese. It was 22 symbols were found in Medya Hus's poems. Medya Hus mostly used the Islamic terms as the symbols to express what he wants to convey in his poems, because almost of Medya Hus's poems related to Islamic concept. And he also used the things and sensory organ as the symbol.

The reasons of using the symbols in Medya Hus's poems, because Medya Hus wants to show the Acehnese culture and their atittude in society, especially about the roles of religion in Aceh. And also to describe about the nature in Aceh. Medya Hus almost used the symbol of religion and society to express the Acehnese culture and their atittute. Because the culture of Aceh is basically Islamic.

\section{Suggestion}

Having seen the results of study, the writer would like to offer the suggestions as follow:

Literary text as one of poem has symbol which has meaning used by the poet in their poem. The literary text can not separated from citizen life, it should be introduce because one of thing which important to observe in appreciate the literary text which to know symbol from the literary text. Poems in 'Jameun Internet' book by Medya Hus in Acehnese should be read by every citizen, because with understand these poems, it will teach people of how should they act in society and the way to keep the culture based on religion concept.

And based on those conclusions, the writer not only hopes the other researcher to analyzed more comprehensively using several theories of semiotic, but also hopes the paper can contribute a supporting reference in analyzing works of literature through semiotic framework. 


\section{Linguistica, Volume 8 Number 4/ 31 December 2019}

\section{REFERENCE}

Abcarian, R., \& Klotz, M. (1980). Literature: The Human Experience . New York: St. Martin's Press.

Bailey, K. D. (1994). Methods of Social Research. New York: The Free Press.

Beaty, J. (2002). The Norton Introduction to Literature. New York: W. W. Norton And Company.

Bergman, D., \& Epstein, D. M. (1987). Heath Guide to Literature (College). Lexington: D.C Heath.

Cable, L. B. (1998). The Gifts of Interpretation. Urbana: Sagamore Publishing LLC.

Chandler, D. (2007). Semiotic the Basics Second Edition. United Stated of America: Routledge.

Eco, U. (1986). Semiotics and Philosophy of Language. Bloomington: Indiana University Press.

Guth, H. P., \& Rico, G. L. (1997). Discovering Literature: Stories, Poems, Plays . New Jersey: A Blair Press Book.

Halliday, M. (1994). Halliday's Introduction to Functional Grammar. London and New York: Routledge .

Ham, S. H. (1992). A Practical Guide for People with Big Ideas and Small Budgets. Golden, Colorado: North American Press.

Handayani, S. (2016). Code and Cultural Meaning of Semiotic in Cerita Calon Arang. Medan: Universitas Negeri Medan.

Harun, M. (2012). Pengantar Sastra Aceh. Banda Aceh: Cita Pustaka Media Perintis.

Hermawan, A. (2010). A Semiotic Analysis on Kim Addonizio's Poems Based on C. S. Peirce's Semiotic Theory. State Islamic University Syarif Hidayatullah.

Jansz, P. C. (1997). Introducing Semiotics. New York: Totem Books.

Karina Kielmann, F. C. (2012). Introduction to Qualitative Research Methodology: A Training Manual. United Kingdom.

Pertiwi, F. (2010). A Semiotic Analysis in Literary Work based on Valentine Poems by Carol Ann Duffy. State Islamic University Syarif Hidayatullah, 1-37.

Pickering, J. H., \& Hoeper, J. D. (1981). Concise Companion to Literature. New York: Macmillan Publishing Co., Inc.

Pierce, C. S. (1991). Pierce On Signs: Writings on Semiotics. North Carolina: University of North Carolina Press.

Samad, S. A. (2015). Character Education Base on Local Wisdom in Aceh (Study on Tradition of Children Education in Aceh Community). Banda Aceh: UIN Ar-Raniry.

Saussure, F. d. (1966). Course in General Linguistics. New York: McGraw-Hill Book Company.

Setiawan, I. (2014). Symbols on Robert Frost's Poems. Malang: Maulana Malik Ibrahim State Islamic University of Malang.

Singh, R. (2011). Eliot's Use of Symbols in "The Waste Land". VSRD Technical and NonTechnical Journal , 326-328.

Thomas, S. A. (2001). Signs: An Introduction to Semiotics. Toronto, Buffalo, London: University of Toronto Press. 